\title{
THE LIBERAL AND LABOUR PARTIES IN NORTH-EAST POLITICS 1900-14: THE STRUGGLE FOR SUPREMACY
}

The related developments of the rise of the Labour Party and the decline of the Liberal Party have been subjected to considerable scrutiny by historians of modern Britain. Their work has, however, had the effect of stimulating new controversies rather than of establishing a consensus view as to the reasons for this fundamental change in British political life.

There are three main areas of controversy. The first concerns the character of the Labour Party prior to 1918, the degree to which it was Socialist or even collectivist and could offer to the electorate policies and an image substantially different to those of the Liberal Party, and the degree to which it merely continued the Liberal-Labour tradition in alliance with, albeit outside the fold of, the Liberal Party. The second concerns the search for an historical turning-point at which Liberal decline and Labour's advance can be said to have become distinguishable. Perhaps the most vital debate centres around the third area of controversy, the nature of earlytwentieth-century Liberalism and the degree to which a change towards a more collectivist and socially radical posture enabled it to contain the threat that the Labour Party presented to its electoral position.

Research into the history of the Labour Party has modified considerably those earlier views of the movement's history which were largely formed by those who had, themselves, been concerned in the party's development. Few would now give such prominence to the role of the Fabian Society as did writers such as G. D. H. Cole and E. R. Pease. ${ }^{1}$ The importance of the Independent Labour Party was emphasised by Dr Pelling in his study of the origins of the Labour Party. ${ }^{2}$ However, the joint work by F. Bealey and

${ }^{1}$ G. D. H. Cole, British Working Class Politics 1832-1914 (1941); E. R. Pease. A History of the Fabian Society (1916).

2 H. Pelling, The Origins of the Labour Party 1880-1900 (1954). 
Pelling, together with subsequent writings by Dr Pelling, ${ }^{3}$ have given pride of place to the role of the trade unions - many of whose leaders were not Socialists - in the formation and development of the party. Historians of Edwardian electoral politics ${ }^{4}$ and of the Liberal Party ${ }^{5}$ have put in doubt the degree to which Labour was, before 1914, a distinctive political force. Above all, perhaps, the concept of the inevitability of the rise of Labour, to become the major party of the Left in British politics, and the consequent decline of the Liberal Party in the 1920's has been attacked, ${ }^{6}$ although $\mathrm{Dr}$ McKibbin ${ }^{7}$ has provided it with a new defence.

Among the reasons put forward by historians for the long-term death of Liberal England, there are three major theories, each with its own timescale. The first sees the Liberal Party as already largely obsolescent by the late nineteen th century: a coalition of interest groups which were no longer central to the Britain of the period, and unable to fashion a new identity relevant to the nation and electorate which were emerging. ${ }^{8}$ The second view sees Liberalism as successful enough until the years immediately before the First World War, in which period it was exposed as being unable to cope with a wave of rising conflict involving industrial unrest, the suffragette agitation and the Irish Question. ${ }^{9} \mathrm{~A}$ view put forward in some recent studies, however, is that the decline of Liberalism must be seen as a post-1914 phenomenon and that early-twentieth-century Liberalism was suffering no serious erosion of electoral support. ${ }^{10}$

Three important regional studies ${ }^{11}$ have examined the political development of Wales, London and Lancashire in the late nineteenth and early twentieth centuries, and have modified the interpretation of the history of the Labour and Liberal Parties during this period. Their conclusions differ widely, but it appears likely that this is not because of errors in historical investigation, but rather because of the non-homogeneous

${ }^{3}$ F. Bealey and H. Pelling, Labour and Politics 1900-1906 (1958); H. Pelling, Popular Politics and Society in Late Victorian England (1968).

4 A. K. Russell, Liberal Landslide: The General Election of 1906 (1973); N. Blewett, The Peers, the Parties and the People: The General Elections of 1910 (1972).

5 T. Wilson, The Downfall of the Liberal Party 1914-1935 (1966).

${ }^{6}$ Ibid.; P. F. Clarke, Lancashire and the New Liberalism (1971).

7 R. McKibbin, The Evolution of the Labour Party 1910-1924 (1974).

8 R. C. K. Ensor, England 1870-1914 (1936).

9 G. Dangerfield, The Strange Death of Liberal England (1935).

10 Wilson, The Downfall of the Liberal Party, op. cit.; R. Douglas. History of the Liberal Party 1895-1970 (1971).

11 K. O. Morgan, Wales in British Politics 1868-1922 (1963); id., "The New Liberalism and the Challenge of Labour: The Welsh experience, 1885-1929", in: The Welsh History Review, V (1972); P. Thompson, Socialists, Liberals and Labour: The Struggle for London 1885-1914 (1967); Clarke, Lancashire and the New Liberalism, op. cit. 
nature of the pre-1914 British electorate and the persistence of regional characteristics in voting behaviour. Whereas K. O. Morgan in his studies of Welsh politics has posited a Welsh Liberalism which was not only able to contain the challenge of Labour, but was strong and resilient while at the same time owing little to new initiatives in social policy, P. Thompson's study of London has shown support for Liberalism as being eroded among working-class voters, who were turning to Labour and Socialism. P. F. Clarke has argued for the emergence of a new Liberalism in Lancashire during this period, a socially radical and collectivist Liberalism, which was able to engage the loyalties of working-class voters while losing some of its traditional middle-class support. He has gone on to argue for the emergence of class politics in their modern form in pre-1914 England, and seen this as a movement from which a transformed Liberalism was able to benefit. ${ }^{12}$ The aim of this article is to consider Liberal and Labour politics in the North-East of England in the period 1900-14 and the response of North-East Liberalism to the challenge from Labour.

Between 1885 and 1918 the North-East, defined as Northumberland and Durham plus Middlesbrough, consisted electorally of twelve county constituencies and eleven boroughs. As Newcastle and Sunderland were both double-member constituencies, the area returned twenty-five MPs. The North-East was a Liberal stronghold. In only one of the county divisions, South-East Durham (and there it was partly due to special circumstances ${ }^{13}$ ), did the Unionists manage to win the seat four times out of the eight General Elections during the period 1885-1910. Three other seats, Houghton-le-Spring, Hexham ${ }^{14}$ and Tyneside, were won by the Unionists on solitary occasions, while the great bulk of the county seats, Durham North-West, Jarrow, Chester-le-Street, Durham Mid Division, Barnard Castle, Bishop Auckland, Berwick and Wansbeck, never saw a Unionist victory between the franchise reform and redistribution of 1884-85 and those of 1918 . The borough constituencies were scarcely less devotedly Liberal. In only two borough seats, Durham City and Tynemouth, did the Unionists win in more than half of the General Elections during the period 1885-1910, while Morpeth, South Shields and Gateshead never returned Unionist candidates. When the Labour Representation Committee sought,

12 P. F. Clarke, "Electoral Sociology of Modern Britain", in: History, LVII (1972).

13 In 1906 the sitting Unionist member F. N. Lambton, a Unionist free-trader, was unopposed.

${ }^{14}$ In 1892 N. G. Clayton won Hexham for the Conservatives, but he was unseated on petition for extensive treating. 
as a new political party, to represent the voice of labour in the House of Commons, it was, in the North-East, faced with a Liberal hegemony that could command the loyalty of the working-class voter and much of the trade-union movement. Any headway that the LRC was to make had to be made not, as in Lancashire, at the expense of Unionism but, as in Wales, at the expense of Liberalism.

Many of the difficulties encountered by the LRC in the North-East were microcosms of its national difficulties. The different elements which came together to form the LRC in February 1900 were, when it came to party organisation, at once its strength and its weakness. Labour was not in the position of a totally new political party having to build up a machine from scratch. Instead the LRC was able to utilise and build upon existing organisations; these were the ILP, the Fabian Society, those trade unions which supported the LRC and trades councils throughout the country (the Social Democratic Federation disaffiliated from the LRC after little more than a year's membership). At both a local and a national level, however, these organisations were often hostile to each other, jealous of their independence and suspicious of attempts by the LRC Executive to control them. Throughout the period 1900-18, although its power increased, the LRC Executive, after 1906 the Labour Party Executive, was not in the position of a unified political party exercising power through its own organisation, but was, rather, attempting to control diverse organisations and set up a national and local framework within which those organisations could work together.

Among the problems of the LRC and later the Labour Party were the difficulty in imposing the Executive's authority over the affiliated organisations, the difficulty of persuading trade unions and trade unionists, with a long history of collaboration with the Liberal Party, to break their ties with Liberalism and come within the Labour fold, and the difficulties of both working with the Liberals, especially after the Gladstone-MacDonald agreement, and retaining a separate identity; in addition, the national organisation was rudimentary and suffered from a lack of funds. ${ }^{15}$ In the North-East of England many of these problems were posed in an acute form.

The North-East had seen the beginning of labour representation when, in 1874, Thomas Burt, the secretary of the Northumberland Miners' Union, had been returned as member for Morpeth. He and Alexander MacDonald were the first two working men to be elected to Parliament.

15 The financial position improved slightly after the 1903 conference, which set up a Parliamentary fund for Labour candidates to be financed by contributions from affiliated societies at the annual rate of $1 \mathrm{~d}$ per member. 
Largely because of their members being concentrated in certain areas, in such large numbers that they often made up the bulk of the electorate, the mining unions had been the most effective in securing seats for their members and, in the 1885 election, four mining MPs were returned in Northumberland and Durham: Burt, Charles Fenwick (Wansbeck), William Crawford (Mid Durham) and John Wilson (Houghton-le-Spring). Wilson lost his seat in the 1886 election but, on Crawford's death, he took over Mid Durham, which he was to retain from 1890 until 1915. In addition to these mining MPs, John Havelock Wilson, the secretary of the Seamen's Union, was elected MP for Middlesbrough in 1892.

Far from paving the way for the LRC, this considerable achievement by way of labour representation presented a formidable obstacle to that organisation. All the mining members had been returned to Parliament, not against the wishes of the Liberal Party, but with its active co-operation and support; they were in fact Liberal-Labour MPs. The mining unions were, by 1900 , seeking to run more candidates, but their Liberal-Labourdominated executives still sought to do this in conjunction with the Liberal Party. Havelock Wilson, although he had started his political career in Middlesbrough as a Labour candidate opposing a Liberal, was by the late 1890 's on good terms with local Liberals and generally considered to be a Liberal-Labour MP.

The Liberal-Labour attitude is well summarised by A. W. Humphrey.

Once formed, political ties are not easily broken. To quote again the view of Mr. Burt, Liberal-Labourism believed that the shortcomings of the rich were due rather to "lack of sympathy than from absence of a desire to do right." In the matter of political tactics, the Liberal-Labour men were diametrically opposed to the rising movement for independence, and were of opinion that independence in the House [of Commons] would weaken rather than strengthen the cause. ${ }^{16}$

The role of Burt in the North-East corresponds closely to that of William Abraham ("Mabon") in Wales, who was secretary of the Cambrian Miners' Association and whom K. O. Morgan has described as "the supreme Lib-Lab". ${ }^{17}$ Burt believed in the "reconciliation of the interests of Labour and of Capital", ${ }^{18}$ and his attitude was shared by other Liberal-Labour MPs and in particular by John Wilson, the MP for Houghton-le-Spring and secretary of the Durham Miners' Association. Liberal-Labourism and sympathy for the Liberal Party among working-class electors were to die

\footnotetext{
16 A. W. Humphrey, A History of Labour Representation (1912), p. 120.

17 Morgan. "The New Liberalism", loc. cit.

18 T. Burt, An Autobiography (1924), p. 252.
} 
hard in the North-East and were to resist the Labour Party's advance so that, even by 1914, the struggle was far from over.

If the Liberal Party had not made the fundamental mistake of neglecting to adopt more Liberal working men as candidates in the late nineteenth and early twentieth centuries, Liberal-Labourism might have been an even more formidable obstacle to Labour. As it was, in the North-East, as elsewhere, local Liberal associations were by no means eager to accommodate the desire of working men to be adopted as candidates. This appears to have been partly due to prejudice and, in the view of Herbert Gladstone, largely because of the desire of local associations to have a candidate who could contribute to the cost of elections and be a "golden source". ${ }^{19}$ Thus a majority of the Newcastle Liberal "One Thousand" overruled their Executive and rejected Arthur Henderson as a candidate in 1895, while even the Durham Miners' Association's request to be allowed to run more candidates met with a tardy response from the Northern Liberal Federation in $1903 .^{20}$

There were, however, positive factors in favour of independent labour representation. As early as 1887 , the SDF and the Socialist League had been active on Tyneside and in the pit villages, and both Tom Mann and William Morris had addressed meetings, the former staying in the area as SDF adviser for some time. ${ }^{21}$ Although the movement lost its impetus and largely died out except on Tyneside itself, the ILP began to be influential in the 'nineties, establishing branches on Tyneside and in the larger Durham pit villages. Despite the "Lib-Labism" of the mining union leadership, there was a nucleus of ILP'ers in many miners' lodges. In Newcastle the ILP had been confident enough to put forward a candidate, F. P. Hammill, ${ }^{22}$ in 1895 , who polled 2,302 votes.

From the beginning then the North-East must have appeared a promising area to the LRC, yet one which was likely to be beset with problems. There was a small but influential and militant number of Socialist activists, although against this had to be set the fact that trade unionism in the area

19 Herbert Gladstone Papers, British Museum, Add. Mss 46106. Ironically, it was the capacity of trade-unionist candidates, when backed by their unions, to be such a "golden source" that was often to predicate the Labour Party's choice of candidates in the future. ${ }^{20}$ Similarly Morgan, "The New Liberalism", finds that in Wales there was severe friction with local Liberal associations over the adoption of two miners' candidates in 1903-04. See also J. Brown, "Attercliffe, 1894: How One Local Liberal Party Failed to Meet the Challenge of Labour", in: Journal of British Studies, XIV (1975).

21 T. Mann, My Memoirs (1923), p. 65; E. P. Thompson, William Morris, Romantic to Revolutionary (1955), pp. 512-25.

22 F. P. Hammill was an ex-Fabian, active in London trade unionism. He played a prominent part in the successful London busmen's strike in 1891 and organised the Amalgamated Omnibus and Tramworkers' Union. 
and, especially, the important mining and shipbuilding unions had a tradition of accommodation with Liberalism. The only seat in the area to be fought by a LRC candidate in the General Election of 1900 was Sunderland. Alexander Wilkie, secretary of the Associated Shipwrights, was the candidate, but as he had strong links with Liberalism and was quite acceptable to the local Liberal Association, his candidature cannot be considered as demarcating the LRC clearly from Liberal-Labourism. In the double-member constituency the Liberals ran only one candidate, a prominent local shipbuilder, G. B. Hunter, and Wilkie and he co-operated closely speaking from the same platform. Wilkie was independent from the Liberal Party in name only, and his poll of 8,842 votes in an election in which two Unionists were elected ${ }^{23}$ was not a significant indicator of the degree of support for a genuinely independent Labour position. ${ }^{24}$

The first serious problem the LRC encountered in the North-East was the choice of a candidate for the Jarrow constituency. Sir Charles Mark Palmer was virtually the creator of the town and had been Liberal MP for the constituency since its inception. He was commonly thought to be unbeatable, and previous Labour candidatures ${ }^{25}$ in 1885 and 1892 had done nothing to shake this belief. By 1902, however, Palmer was extremely ill and thought to be dying. A struggle developed within the ranks of LRC supporters in Jarrow as to whether the LRC candidate should be the moderate and pro-Liberal Alexander Wilkie or the Socialist ILP'er and secretary of the Gasworkers' Union, Pete Curran. Wilkie gained his support largely from the members of his own union, the Shipwrights, and from the other shipbuilding unions, while Curran's support came from the local Socialist organisations and from some of the miners' lodges. A row developed as to whether a meeting of the Jarrow Labour League which chose Curran as candidate on 23 April 1902 had been constitutional. The National Executive of the LRC detailed three of its members to go to Jarrow and enquire into the position. ${ }^{26}$ The situation was that there was not merely a clash between two individuals or even two unions; the division of opinion in Jarrow was one that ran throughout the labour movement up to the LRC Executive itself. It is not surprising, therefore, that the delegation

23 Cons. 9,617, Cons. 9,566, Lib. 9,370, Lab. 8,842.

24 In this it resembles the contest at Derby, the only other double-member constituency to be fought by one Liberal and one LRC candidate, and where Richard Bell co-operated closely with the Liberal.

25 In 1885 James Johnston stood as a Labour candidate (C. M. Palmer (Lib.) 5,702, M. J. Johnston (Lab.) 1,731) and in 1892 Dillon Lewis stood as a Labour or Democratic candidate (Sir C. M. Palmer (Lib.) 7,343, D. Lewis (Lab.) 2,416).

${ }^{26}$ LRC National Executive Committee Minutes, 9 May 1902, Pease Collection, British Library of Political Science, London. 
sent by the Executive split and submitted two opposing reports, a majority report supporting Wilkie and a minority report supporting Curran. At a meeting on June 11 the National Executive Committee legitimised Curran's adoption by seven votes to five (Curran, J. Parker, K. Hardie, J. Sexton, J. Hodge, W. Pickles and A. Gee; Wilkie, E. R. Pease, F. Rogers, W. B. Cheesman and C. Freak). ${ }^{27}$ The dispute reveals the division within the LRC between those deeply suspicious of Socialism and wishing to co-operate closely with Liberalism, and those, mainly ILP'ers, pressing for an independent and Socialist political party.

By the time of the third annual conference of the LRC held at Newcastle in February 1903, plans were being made to adopt candidates in readiness for a General Election at Darlington, Stockton on Tees, Barnard Castle and Sunderland. In March 1903 Isaac Mitchell of the Engineers' Union was formally approved as candidate for Darlington, and in May approval was sought from the LRC for Arthur Henderson of the Ironfounders' Union and Thomas Summerbell, a member of the ILP, as candidates for Barnard Castle and Sunderland, respectively. In April Frank Rose of the Engineers' Union was adopted as LRC candidate for Stockton.

\section{III}

As the organisation of the LRC in the North-East expanded and as new candidates were selected, so the problems as to what attitude to take to local Liberalism and to Liberal-Labour MPs became more urgent. The question of the LRC's relationships with the major political parties and particularly with the Liberal Party was, of course, a national and not a purely local problem, and provided the main issue at the Newcastle conference. There were, in the main, three different attitudes towards relations with the Liberal Party within the LRC. There were those like Richard Bell, E. R. Pease and Alexander Wilkie who did not really want the LRC to be an independent party at all, but merely wished for a pressure group that would vote together on labour questions and would, otherwise, have local understandings with the Liberal Party. There were those like Curran, J. Bruce Glasier and many of the ILP who wanted a completely independent and Socialist party which would fight Liberalism as hard as it would fight Unionism. Finally there was the attitude shared by Ramsay MacDonald and Keir Hardie, which saw the advantages of an electoral pact with the Liberal Party, but saw that this could be more advantageous if made from a position of strength; they wished in short to be independent of the Liberal Party in order to come to terms with it.

27 Ibid., 11 June. 
The expansion of the LRC to the point where it was likely to become a considerable electoral force in the area, was unacceptable to local Liberalism. Although, during the summer of 1903, MacDonald and Herbert Gladstone were moving towards the policy of electoral alliance which was to be fully agreed upon in September, in the North-East there was not the easy co-operation that was to be found in much of the country. The leadership of Northern Liberalism awoke early to the threat posed by the LRC, as did many of the Liberal-Labour MPs and candidates. The Northern Liberal Federation appears to have launched an attack upon the LRC and in the forefront of that attack was the Liberal-Labour element. The selection of Liberal candidates moved on apace, even in constituencies, like Stockton, where the LRC plans were well advanced, and the putting up of Hubert Beaumont in opposition to Arthur Henderson at Barnard Castle was to be another sign of the Northern Liberals' determination to stand firm against the LRC. Thomas Burt and Havelock Wilson were prominent among Liberal-Labour men who bitterly attacked the LRC, the latter playing a double game of opposing the LRC yet complaining to its chairman of MacDonald's interference in Middlesbrough. ${ }^{28}$

The growing challenge of the LRC to Liberalism in Durham frightened not only local Liberals, but that section of the LRC whose political roots and attitudes were so close to Liberalism that they were much happier in alliance with, than in opposition to it. Within this section were two of the candidates, Isaac Mitchell and Arthur Henderson. Both became increasingly worried as the list of LRC candidates grew and the possibility of their being opposed by Liberals grew with it. ${ }^{29}$ The resistance of North-East Liberalism to the LRC's advance was, however, to be blunted both by internal divisions within the region and by pressures from the national Liberal leadership pursuing its policy of electoral accord with Labour. Although many leading North-East Liberals, including prominent industrialists and businessmen, together with the Liberal-Labour MPs were opposed to making way for Labour, there was, what may be termed, a "progressive alliance" element prepared to ally with Labour and make way for it in certain seats.

The traditional character of North-East Liberalism in the late nineteenth century had been marked by the dominance of industrial entrepreneurs with a leavening of trade-unionist Liberal-Labour MPs. Dr Morgan has remarked on the "deep chasm between capital and Labour that scarred

28 Ibid.. 18 June.

${ }^{29}$ I. Mitchell to J. R. MacDonald, 6 May 1903; A. Henderson to id., 19 May, Labour Party Letter Files, Transport House, London. 
industrial relations in England" and has contrasted this with the "socially and culturally homogeneous" nature of Welsh Liberalism. ${ }^{30}$ No observer of North-East Liberalism in the 1890's would have detected such a deep chasm and, if Liberalism in the area lacked the cementing influence of national and cultural separatism, it was certainly not rent by the class war. Liberal-Labour MPs like Burt, Fenwick and John Wilson shared many assumptions and ideals with industrialists like James Joicey, coal-owner, Sir Charles Mark Palmer, shipbuilder, and Sir Walter Runciman, shipowner.

It was this traditional alliance which led the Liberal opposition to the LRC, and although by the early twentieth century the influence of the great industrialist Liberals was on the wane from its zenith in the late nineteenth century, it remained considerable. Another grouping of Liberals who were as opposed to the development of independent labour representation were the Liberal Imperialists. They have often been described by historians as social imperialists, for they were aware of both the relative decline of Britain as a world power and of the dangers of class-orientated politics, and believed that a combination of imperialism, national efficiency and social reform could both arrest Britain's decline and prevent the development of class antagonism. Differences between this group, whose leadership included Lord Rosebery, Asquith, Sir Edward Grey and R. B. Haldane, and those Liberals less enthusiastic for, or opposed to, imperialism came to a head during the Boer War, with the Liberal Imperialists supporting the war, Campbell-Bannerman in company with Morley and Harcourt disapproving of it, and a "Little Englander" section under the leadership of Lloyd George opposing it outright. Members of the Liberal League, the organisation of Liberal Imperialism formed in 1902 by Rosebery, who were influential in North-East Liberalism included J. M. Paulton, Liberal MP for Bishop Auckland, S. F. Mendl, Liberal candidate for Stockton on Tees, Walter Runciman Jun., son of the shipping magnate and himself MP for Dewsbury, and, of course, Sir Edward Grey, member for Berwick upon Tweed and a vice-president of the League. That which could bind together Liberal Imperialists, with their faith in Empire and past support for the Boer War, and those with a more Gladstonian attitude towards foreign and imperial affairs was a common detestation of class as a determinant of political activity. Industrialists like Palmer, trade unionists like Burt and Liberal Imperialists like Grey could unite in believing that class was, at any rate in the long run, either irrelevant or capable of being made irrelevant to the real business of politics, for class animosity arose either from a want of

${ }^{30}$ Morgan. "The New Liberalism”, p. 290. 
understanding and sympathy or from the failure of national policies to produce a cohesion which transcended class.

There was, however, a section of North-East Liberalism much more favourably disposed to the development of the LRC. John Mackinnon Robertson, adopted Liberal candidate for Tyneside, was one of a growing number of writers and journalists who became Liberal candidates in the early twentieth century. ${ }^{31}$ His views were more avowedly collectivist than those of many LRC supporters and H. V. Emy has seen him as one of the most influential of "social radicals" within the Liberal Party. ${ }^{32}$ Other prominent North-East Liberals favourable to a "progressive alliance" with the LRC included Atherley Jones, MP for North-West Durham and son of Ernest Jones the Chartist leader, and the Liberal candidates for Sunderland, Tynemouth and Newcastle, respectively J. Stuart, J. Craig and T. Cairns, though only Robertson and Atherley Jones can properly be referred to as social radicals.

There were thus two views among North-East Liberals as to what attitude to take to the LRC, and the situation was complicated by the interest of the national leadership of the party in a smooth working of the electoral understanding with Labour. It is clear, however, that few Liberals regarded the $L R C$ as a monolithic organisation and that, when considering whether or not to oppose a LRC candidate, the views of the candidate and whether he was prepared to identify closely with Liberalism were important. If members of the LRC were, themselves, unsure as to whether they were part of a new political party or a pressure group for the interests of labour, and if the membership of that party included those whose views were virtually indistinguishable from Liberal-Labourism and those whose views were avowedly Socialist, it is not surprising that Liberals disagreed as to the attitude to take towards such an organisation.

The circumstances of Arthur Henderson's election as MP for Barnard Castle in July 1903 provide graphic illustration of the divisions and confusions prevailing within both the LRC and the Liberal Party. This was an event of major importance for the LRC, and an important stage in the development of relations between Liberal and Labour nationally and in the North-East. It was the third by-election to be won by Labour and the first single-member seat to be won in a three-cornered contest involving a Liberal as well as a Conservative candidate. Like the Woolwich and Clitheroe by-elections, however, Barnard Castle cannot properly be seen as

31 H. V. Emy, Liberals, Radicals and Social Politics (1973), p. 103, analyses the composition of the Parliamentary Liberal Party, 1892-1900, and shows the number of publishers, writers and journalists to have reached a peak after the 1906 election.

32 Ibid. 
an unequivocal sign of Labour strength vis-a-vis Liberalism but appears, rather, to have been the result of the Liberal Party's failure to adopt working-class candidates in the 1890's. The fact that the Liberal Party's national organisation was reluctant to oppose such candidates as Will Crooks at Woolwich, David Shackleton at Clitheroe and Arthur Henderson at Barnard Castle, and that all three had been Liberals or closely associated with the Liberal Party makes it impossible accurately to quantify the strength of feeling for independent labour representation in these constituencies.

The decision of the Barnard Castle Liberal Association to adopt Hubert Beaumont as Liberal candidate to oppose Arthur Henderson, the Liberal agent until early in 1903 who had been adopted LRC candidate for the constituency in April, was supported by only a section of North-East Liberalism and disapproved of by the national leadership. ${ }^{33}$ Henderson himself was uneasy about standing with Liberal opposition and might well have withdrawn had not the death of the sitting member Sir Joseph Pease in June 1903 precipitated the contest. In the course of the campaign Henderson went a long way towards Liberal-Labourism in an effort to capture Liberal votes, promising to support the "Lib-Lab" miners' candidates and warning off ILP speakers from coming to his aid. In many ways he appeared a more orthodox Liberal than Hubert Beaumont, as the latter was compromised by the revelation that his leading supporter, Samuel Storey, chairman of the Northern Liberal Federation, was favourable to tariff reform. Many Liberal newspapers failed to support Beaumont, including Rowntree's Northern Echo, which had a deep commitment to the "progressive alliance" concept. F. Bealey and H. Pelling have noted that "No prominent Liberal speakers supported Beaumont, and the usual letters and telegrams of encouragement from headquarters and from parliamentary leaders were noticeably lacking." 34

The Barnard Castle result was not a catastrophe for North-East Liberalism, but was rather a setback for the policy of some North-East Liberals who sought to meet the LRC challenge head-on. Samuel Storey, veteran radical and newspaper proprietor, headed those Liberals who felt that by compromising with Labour candidates who were not within the fold of Liberalism the Liberal Party was selling the pass. As he wrote three years later: "The fate of the Liberal Party, unless experience teaches it wisdom, will doubtless be that of the German National Liberal Party which

${ }^{33}$ For an account of Henderson's early career and of the Barnard Castle by-election, see A. W. Purdue, "Arthur Henderson and Liberal, Liberal-Labour and Labour Politics in the North-East of England 1892-1903", in: Northern History, XI (1976 for 1975).

34 Bealey and Pelling, Labour and Politics, op. cit., p. 154. 
coquetted with Socialism till Socialism, grown strong, destroyed it as a political force." 35 Storey was, however, soon to resign from the Liberal Party over the question of tariff reform, but many other leading Liberals saw the danger of too generous an accommodation of the LRC. Walter Runciman was Storey's successor as chairman of the Northern Liberal Federation and continued his policy of opposing LRC candidates.

Runciman was determined that, in the event of Sir Charles Mark Palmer being unable to stand again for Jarrow, a new Liberal candidate must be found to oppose Pete Curran. ${ }^{36} \mathrm{He}$ was also eager that two Liberals should stand for Newcastle and tried to persuade John Morley to return to his former constituency. ${ }^{37}$ Sir Charles was able to contest Jarrow at the 1906 election, but in Newcastle, as at Sunderland, both the LRC and the Liberals followed the policy of electoral alliance and fielded only one candidate each. In only two other seats, however, were LRC candidates in the North-East to be without Liberal opposition. There was no Liberal candidate at Barnard Castle in the General Election of 1906 and none at Darlington either, which was not surprising as the LRC candidate, Isaac Mitchell, was indistinguishable in policy from a Liberal.

There were thus four seats in the region at the General Election of 1906 where co-operation existed (Darlington, Barnard Castle, Newcastle and Sunderland), but there were also four in which Labour and Liberal supporters were on opposing sides. In only two of these four, Jarrow and Stockton, were the Labour candidates officially backed by the LRC, but in Chester-le-Street and Middlesbrough, which had respectively a Labour and a Socialist candidate, there was considerable unofficial backing from the LRC. In Chester-le-Street J. W. Taylor stood as the official candidate of the Durham Miners' Association, but he was a member of the ILP and broke with the tradition of Liberal-Labourism by standing as a Labour candidate. In all senses but the narrowly technical he was a LRC candidate and was opposed by a Liberal candidate, Rev. A. B. Tebb. Like Beaumont at Barnard Castle in 1903, Tebb got very little support from the national Liberal leadership. He claimed to be a Liberal-Labour candidate, but as a nonconformist minister and a tea-salesman his claim to the Liberal-Labour label is debatable. ${ }^{38}$ George Lansbury at Middlesbrough failed to get recognition from the National Executive of the $L R C$, and stood as a

35 Newcastle Daily Chronicle, 12 January 1906.

36 Runciman Sen. to W. Runciman Jun., 19 March 1905, Runciman Papers, University of Newcastle upon Tyne Library.

37 Sir W. Runciman, Before the Mast and After (1924), pp. 276-77.

38 It is, probably, safest to reserve the label "Liberal-Labour" for trade-union candidates supporting the Liberal Party. 
Socialist against the sitting Unionist and the ex-Liberal-Labour member Havelock Wilson, but he received strong support from Ramsay MacDonald and Keir Hardie. ${ }^{39}$ As there were four seats (five if we include Rev. Tebb at Chester-le-Street) in which Liberal-Labour candidates were standing, ${ }^{40}$ support for the older Liberal policy of labour representation within the Liberal Party can be seen to have been as strong among NorthEast Liberals as support for the newer policy of the Gladstone-MacDonald understanding.

The Labour Party emerged from the 1906 General Election with four MPs in the area (Chester-le-Street, Barnard Castle, Newcastle and Sunderland), ${ }^{41}$ but this success can be misleading. The only candidate in the area to campaign on an avowedly Socialist platform was George Lansbury, though Thomas Summerbell at Sunderland, a member of the ILP, laid an emphasis on the conflict between capital and labour, and argued for a greater degree of state and municipal ownership than did most Labour candidates. For the most part, however, even ILP'ers like Taylor and Curran played down their Socialism, preferring to emphasise their trade unionism, and most LRC candidates were virtually indistinguishable from Liberals in the policies they campaigned on.

In an election where there was nationally a tacit alliance between the LRC and the Liberal Party it is, perhaps, not surprising that in constituencies where the electoral agreement worked there was a common emphasis on "progressive" policies. Even where Labour and Liberal candidates opposed each other as at Jarrow, Chester-le-Street and Stockton, however, Labour candidates did not so much attack Liberal ideology and policies as concentrate upon the need for labour to be represented by the Labour Party. There is little evidence to point to the achievement of the LRC in having four candidates returned to Parliament for the region, as the outcome of a widespread demand among the North-East electorate for a party distinctly separate from the Liberal Party. Rather the advent of Labour was the outcome of the electoral alliance and the feeling of the Liberal Party national leadership that the achievement of office and the

39 For an account of Lansbury's campaign in Middlesbrough, see A. W. Purdue, "George Lansbury and the Middlesbrough Election of 1906", in: International Review of Social History, XVIII (1973).

40 Wansbeck, Morpeth, Durham Mid Division, Middlesbrough.

41 Chester-le-Street: J. W. Taylor (Lab.) 8,085, S. D. Shafto (Union.) 4,895, Rev. A. B. Tebb (Lib.) 4,606; Barnard Castle: A. Henderson (Lab.) 5,540, Capt. E. Bell (Union.) 3,888; Newcastle upon Tyne: W. Hudson (Lab.) 18,869, T. Cairns (Lib.) 18,423, Sir W. R. Plummer (Union.) 11,942, G. Renwick (Union.) 11,233; Sunderland: J. Stuart (Lib.) 13,620, T. Summerbell (Lab.) 13,430, D. H. Haggie (Union.) 7,879, J. S. G. Pemberton (Union.) 7.244 . 
defeat of Unionism were more important than any long-term threat from Labour.

The electoral compact between the LRC and the Liberal Party had, at best, worked imperfectly in the region, and had had a demoralising and divisive effect upon the North-East Liberalism. Prominent Liberals in the area had seen their advice disregarded, while local Liberal Associations were often overruled as the national leadership and a section of the local party enforced obedience to the détente with Labour. Some had fought back, as in Jarrow and Chester-le-Street, but had been given little support. North-East Liberals could look back upon a period since 1903 in which four seats had been lost or given away to Labour. From 1906 onwards, however, there were to be no further concessions by the Liberals. In fact the period 1906-14 sees the Liberal Party in the North-East fighting back and enjoying great success while doing so.

On the death of Sir Charles Mark Palmer in 1907, the Jarrow Liberals adopted as candidate S. Leigh Hughes, a London journalist. Pete Curran had been assiduously nursing the constituency in the Labour interest. In the by-election there was not the straight fight between Labour and Liberal there had been in 1906. There was also a tariff-reforming Unionist and an Irish Nationalist. As in 1906 Curran played down his Socialism and emphasised his trade-union record, not mentioning Socialism in his election address. Although his share of the poll actually went down by five per cent, he was, nevertheless, elected with a majority of 768 over the Unionist. ${ }^{42}$ The Labour victory, as Dr Pelling has pointed out, ${ }^{43}$ was a result of the division of those forces which had voted for Palmer in the General Election. Along with Victor Grayson's victory at Colne Valley in the same year, the result was erroneously greeted by Socialists as the sign of a dawning Socialist electoral popularity.

On the death of the Liberal member for Newcastle (T. Cairns) in 1908 a by-election was held. The Newcastle Trades Council and the local LRC were keen to contest the election and favoured J. J. Stephenson of the Amalgamated Society of Engineers as candidate. Fearing the consequences of a breakdown of the electoral understanding in doublemember constituencies, the National Executive of the Labour Party passed

42 P. Curran (Lab.) 4.698, P. Rose-Innes (Union.) 3,930, S. L. Hughes (Lib.) 3,474, J. O'Hanlon (Irish Nation.) 2,122.

${ }^{43}$ H. Pelling, "Two By-elections: Jarrow and Colne Valley, 1907", in Popular Politics and Society in Late Victorian Britain, op. cit. 
a resolution declaring it not to be in the interests of the labour movement to contest the seat. ${ }^{44}$ In the absence of a Labour candidate E. R. Hartley stood as a Socialist backed by the Newcastle Socialist Institute, the SDF and many members of the ILP and LRC in Newcastle. The Conservative candidate, G. Renwick, fighting a strongly tariff-reformist campaign, defeated the Liberal E. Shortt by 2,143 votes ${ }^{45}$ Hartley gained 2,971 votes and his intervention was obviously a factor in the Liberal defeat, although the Newcastle Irish may have voted against Shortt or abstained due to the banning of a Catholic religious procession in London by the government. ${ }^{46}$

In 1907, the Durham Miners' Association and the Northumberland Miners' Mutual Confident Association voted to affiliate with the Miners' Federation of Great Britain. In the past the ILP element within these unions had favoured affiliation and the Liberal-Labour element had opposed it. A major reason for the failure of the North-East unions to join the MFGB had been the latter organisation's support for a bill to enforce an eight-hour day. The hewers who dominated the Northumberland and Durham unions were already working a seven-hour day. The decision of the Liberal government to bring in an Eight Hours Bill had, however, destroyed the economic case for keeping out of the MFGB. In 1908, however, the MFGB voted to affiliate to the Labour Party, and this meant that the North-East miners, also, must affiliate to that party and that their MPs must cease to be Liberal-Labour MPs and sign the Labour Party constitution. For J. W. Taylor this was no problem and J. Johnson, who was initially opposed to doing so, eventually signed, but Burt, Fenwick and Wilson refused to disavow the political beliefs of a lifetime and declined to sign the constitution. ${ }^{47}$

In the General Election of January 1910, the DMA ran three official candidates, all of whom stood as Labour candidates: J. W. Taylor (Chester-le-Street), J. Johnson (Gateshead) and W. House (Bishop Auckland). J. Wilson (Mid Durham) stood with the backing of his local Liberal Association, but the general secretary of the union was not a union candidate. Liberal candidates were adopted against both Johnson and House. Despite pressure from the local LRCs at Morpeth and Wansbeck and from ILP supporters within the union, the Northumberland union decided not to run official candidates in 1910. To have done so might well have meant opposing their own general secretary. Burt and Fenwick stood and were elected with the support of their local Liberal associations.

44 LRC National Executive Committee Minutes, 10 September 1908.

45 G. Renwick (Union.) 13,863, E. Shortt (Lib.) 11,720, E. R. Hartley (Soc.) 2,971.

46 The Times, 22 September 1908.

47 Accounts of the efforts made to persuade the Lib-Labs to sign the constitution are contained in the Minute Books of the NMMCA and the DMA. 
By 1909 the Liberals in the North-East were in no mood to give ground to the Labour Party. In the summer of 1909, the Northern Liberal Federation was reorganising the Liberal associations in Jarrow, Gateshead, Stockton and Barnard Castle. On the eve of the General Election of 1910, the Durham Liberals did, however, suggest a compromise by which the Liberals would refrain from contesting Barnard Castle, Chester-le-Street and Jarrow if the Labour Party withdrew from Gateshead and Bishop Auckland and contested two Unionist-held seats instead. The Labour Party, rather overestimating its strength, refused. ${ }^{48}$

Although the Northern Liberal Federation would have preferred to go over to the offensive, national Liberal policy towards the Labour Party in 1910 was to be one of containment. Labour was to be confined to those seats won in 1906. J. A. Pease, Liberal Chief Whip, spelt out this policy in a letter to the Liberal Association of Bishop Auckland, advising that "Liberals, so far as they can, should respect the seats which at the last general election returned L.R.C. candidates" ${ }^{49}$ North-East Liberals could claim that they kept to the letter of Pease's policy, for in none of the seats in which LRC candidates had been successful in 1906 was a Labour candidate opposed by a Liberal. In Gateshead and Jarrow, however, sitting Labour members were opposed by Liberals in 1910, and in Bishop Auckland and Middlesbrough, both of which were held by Liberals in 1906, there were Labour candidates. Unionists also stood in these four constituencies and in all except Jarrow, where Curran was in second place, Labour came bottom of the poll. The Chester-le-Street Liberal Association set up a sub-committee to secure a candidate to oppose Taylor, but after consultation with Pease it was decided that it would not be prudent to contest the seat. There was no move by the Barnard Castle Liberals to oppose Henderson. ${ }^{50}$ In Newcastle and Sunderland the electoral compact continued. Labour went into the General Election with six MPs in the region (Johnson now being Labour) and emerged with three ${ }^{51}$ Curran, Johnson and Summerbell were defeated ${ }^{52}$ (the latter along with a Liberal

48 R. Gregory, The Miners and British Politics 1906-1914 (1968), p. 78.

49 Blewett, The Peers, the Parties and the People, op. cit., p. 234.

50 By 1912, the Barnard Castle Liberals were determined to oppose Henderson at the next election. Emy, Liberals, Radicals and Social Politics, op. cit., p. 287.

51 Barnard Castle: A. Henderson (Lab.) 6,136, H. G. Stobart (Union.) 4,646; Chesterle-Street: J. W. Taylor (Lab.) 12,634, S. D. Shafto (Union.) 6,891; Newcastle upon Tyne: E. Shortt (Lib.) 18,779, W. Hudson (Lab.) 18,241, Sir W. R. Plummer (Union.) 14,067, G. Renwick (Union.) $13,928$.

52 Jarrow: G. Palmer (Lib.) 4,885, P. Curran (Lab.) 4,818; Gateshead: H. Elverstone (Lib.) 6,800, N. G. Doyle (Union.) 6,323, J. Johnson (Lab.) 3,572; Sunderland: S. Storey (Independent Tariff Reform) 12,334, J. Knott (Union.) 12,270, Rt Hon. J. Stuart (Lib.) 11,529, T. Summerbell (Lab.) $11,058$. 
when Sunderland was won for tariff reform by Samuel Storey and James Knott).

The fortunes of the official miners' candidates in this election were not helped by the continuing opposition of the rank-and-file membership of the DMA to the eight-hour day due to come in to force on 1st January 1910. Although Taylor was again successful at Chester-le-Street, both House, known as a leading supporter of the Eight Hours Bill, and Johnson encountered widespread hostility from members of their own union. A crowd of some 2,000 rioting miners marched through Gateshead, expressing opposition to Johnson and the eight-hour day. ${ }^{53}$ In Jarrow, the Liberal Association had adopted as candidate Godfrey Palmer, Sir Charles' younger son. He attacked Curran's "little navy views" and argued that, at a time when local shipbuilding was doing badly, a businessman of influence was needed to represent Jarrow. There was no Irish Nationalist candidate as in 1907 and the Irish were directed by their leaders to support Palmer. About 1,000 voters in the division had been disenfranchised for accepting poor relief and this may have been a factor counting against Curran ${ }^{54}$ The Middlesbrough Liberal and Labour Association was unable to persuade Havelock Wilson to contest the seat again and attempted to find another Liberal-Labour candidate. A number of Liberal-Labour figures were willing to stand but failed to get support from their unions. Penrys Williams, an iron master, was then chosen as Liberal candidate and Patrick Walls, a steel worker, was selected by the Middlesbrough LRC. Williams won a convincing victory, with a majority of 2,914 over the Unionist candidate. ${ }^{55}$

The feeling of North-East Liberals as to the attitude which should be taken towards Labour was expressed by Sir W. Robson, the Attorney General, who retired from that office in 1910 and did not contest South Shields in December. He opposed both conciliating Labour in the constituencies and giving way to their demands for a reversal of the Osborne Judgement, which would augment Labour's finances. In a memorandum to Asquith he argued:

the Liberal party will be driven to more open and direct battle with the Socialists in the constituencies. Nothing can avoid this conflict [...]. The question is whether we should recognise the inevitable at once or try to stave

53 The Times, 18 January 1910. Bishop Auckland: Sir H. Havelock-Allen (Lib.) 5,391, W.

C. Chaytor (Union.) 3,841, Ald. W. House (Lab.) 3,579.

54 A further factor in Curran's defeat may well have been that he had recently been fined for being drunk and disorderly outside the Palace of Westminster.

55 P. Williams (Lib.) 9,670, C. Dorman (Union.) 6,756, P. Walls (Lab.) 2,710. 
it off for yet a little longer until the Socialist organisation, by our own assistance, have got command of this enormous war chest. ${ }^{56}$

After their considerable setback in January, Labour contested only six seats in December 1910. They put up candidates in Chester-le-Street, Bishop Auckland, Jarrow, Barnard Castle, Newcastle and Sunderland. Taylor was unopposed at Chester-le-Street and Henderson was successful against a Unionist at Barnard Castle, although his majority was reduced for the second time since $1906{ }^{57}$ Liberal candidates again won Jarrow and Bishop Auckland. Pete Curran had died in February, only one week after the previous election, and the new Labour candidate A. G. Cameron of the Carpenters and Joiners' Union was bottom of the poll. ${ }^{58}$ Alderman House managed to improve his position at Bishop Auckland relative to January by pushing the Unionist candidate in to third place. ${ }^{59}$ Labour's solitary gain was at Sunderland, which reverted to being Labour and Liberal. ${ }^{60}$

In 1913 a by-election was held in Houghton-le-Spring after the retirement of the venerable Liberal member R. Cameron. Alderman House was adopted as Labour candidate and Tom Wing, a commercial traveller who had previously sat for Grimsby, was adopted Liberal candidate. There was also a Unionist candidate, T. Richardson. Despite the fact that House was president of the DMA, it was estimated that nine-tenths of the collieries in the division were represented at Wing's adoption meeting and the chairman of the Liberal Association claimed that it was composed entirely of miners. ${ }^{61}$ In a constituency in which the majority of voters were miners, the official candidate of the DMA was beaten into third place and the Liberal candidate returned to Parliament. ${ }^{62}$

When in 1914, Atherley Jones, Liberal member for North-West Durham, was appointed a judge and resigned his seat, the Liberal Association adopted A. Williams, a director of a Middlesbrough firm of iron masters. The North-West Durham LRC had already adopted G. H. Stuart of the Postmen's Union. Although the DMA supported Stuart, the miners of the constituency showed that, like those of Houghton-le-Spring, they were by no means united in support for the Labour Party for, in what was again a mining constituency, the Labour candidate came bottom of the

56 N. Blewett, "The General Elections of 1910" (Ph.D. thesis, Oxford, 1967), p. 249.

57 A. Henderson (Lab.) 5,868, H. G. Stobart (Union.) 4,423.

58 G. Palmer (Lib.) 5,097, J. Kirkby (Union.) 4,986, A. G. Cameron (Lab.) 4,892.

${ }^{59}$ Sir H. Havelock-Allen (Lib.) 4,531, Ald. W. House (Lab.) 3,993, G. E. Markham (Union.) 3,519.

${ }^{60}$ H. Greenwood (Lib.) 11,997, E. W. Goldstone (Lab.) 11,291, W. Joynson-Hicks (Union.) 10,300, S. Samuel (Union.) 10,132.

61 Gregory, The Miners and British Politics, op. cit., p. 80.

62 T. Wing (Lib.) 6,930, T. Richardson (Union.) 4,807, Ald. W. House (Lab.) 4, 185. 
poll and Williams was elected. ${ }^{63}$ In 1914, Labour had thus made no further gains in the North-East but had, indeed, lost spectacularly in two byelections. North-East Liberalism had rallied in the face of the threat from Labour and had shown that its popularity among working-class electors was still considerable.

There is, of course, a considerable division of opinion as to the significance of by-election results in the years 1910-14 as pointers to the respective strengths of the Liberal and Labour Parties. Historians such as Roy Douglas $^{64}$ and Trevor Wilson ${ }^{65}$ have argued that Labour's showing in three-cornered by-elections was poor, and have seen this as evidence that Labour was unlikely to make a substantial advance at the expense of the Liberal Party at a general election held in 1914 or 1915. Ross McKibbin has attacked this interpretation and has seen many of the results as encouraging. Excluding the four seats Labour actually lost as being "unrepresentative", he sees the twelve other by-elections as good results, although he is forced to qualify this in respect of the three Scottish byelections. ${ }^{66} \mathrm{P}$. F. Clarke has criticised his findings, writing that "Dr McKibbin rests his case too largely on extolling or extenuating the Labour poll in individual elections, without applying a proper yardstick, and on the assumption that good first contests were the warranty of future progress. The real question is not whether Labour could do well once, as a flash in the pan. It is whether its strength was growing to the point where it could win seats. Where subsequent contests by Labour can be measured on a comparable basis, the evidence is that it was incapable of extending, or even holding, its initial bridgeheads." 67 As Neal Blewett has pointed out in respect of seats which had three-cornered contests in both 1906 and January 1910, "The evidence suggests that, if Labour failed on the first occasion, a process of attrition set in, a process accentuated if Labour intervention cost the anti-Unionists the seat." 68 McKibbin's claim that the North-West Durham and Houghton-le-Spring results were, "on any judgement, good ones" for Labour can only be substantiated by considering the Labour Party as distinct from the DMA. For a party to contest seats

\footnotetext{
63 A. Williams (Lib.) 7,241, J. O. Hardicker (Union.) 5,564, G. H. Stuart (Lab.) 5,026.

${ }^{64}$ Douglas, History of the Liberal Party, op. cit., pp. 86-90.

65 Wilson, The Downfall of the Liberal Party, op. cit., p. 19.

66 McKibbin, The Evolution of the Labour Party, op. cit., pp. 83-84.

67 P. F. Clarke, review of McKibbin, op. cit., in English Historical Review, XCI (1976), p. 161.

68 Blewett, The Peers, the Parties and the People, p. 394.
} 
for the first time and gain over a quarter of the poll in both cases is at first sight a good result, but when we consider that both candidates were supported by the miners' union and that one of them was an official of that union and we consider the strength of the union in those constituencies, the picture looks very different. The DMA had in the past provided the Liberal-Labour MP for Houghton-le-Spring and more recently had refrained from opposing the aged ex-schoolmaster $\mathbf{R}$. L. Cameron. In North-West Durham the union had given its support to its legal adviser, Atherley Jones. In both constituencies the majority of the electorate were miners and the DMA clearly regarded both seats as naturally "mining seats". Both results were clearly a rebuff to the DMA and its new policy of support for the Labour Party, and bear witness to its failure to convert its membership to that policy.

Labour's success in winning four North-East seats in 1906 had owed much to the pressure of the national Liberal leadership in its pursuit of the Gladstone-MacDonald understanding and to divisions within Northern Liberalism. The policy of making way for Labour candidates had been resisted, both by a section of the Northern leadership and by grass-roots Liberalism in the constituencies, from Barnard Castle in 1903 to the General Election of 1906. Labour, by 1906, had a foothold in the Parliamentary representation of the area. It was not to win a majority of the region's seats until 1922. The progress which had been made by 1906 undoubtedly owed a great deal to the astute handling of LRC affairs by its secretary, Ramsay MacDonald. It is clear from the Labour Party Letter Files that he took the keenest interest in every constituency, used his tact to iron out many difficulties and, his eyes on the realities of power and not the niceties of ideology, helped to retain both Socialists and ex-Liberals within the party and to squeeze the last drop of advantage out of the Liberal alliance without losing his party's independence.

The outcome of the 1906 election had rather flattered Labour strength in the North-East. Skilful negotiations at a national level had enabled Labour to achieve a result which the grass-roots strength of the Labour Party in the area hardly warranted. By 1910 Labour was far stronger in organisation and had the support of all the principal trade unions in the area; most importantly, the influence of the Liberals on the executives of the mining unions had declined and these unions were now affiliated to the Labour Party. Yet Labour's electoral performance was rather worse in 1910 than it had been in 1906, and by 1914 election results were not reflecting its growing organisation and its support from organised labour. By 1914 the hold of the Liberal Party on the Parliamentary representation of the North-East was little dented. Of the twenty-five MPs representing the 
region nineteen were Liberals. Liberal success had been based largely on a re-awakening of confidence in the face of the threat from Labour, together with an absence of pressure from the leadership for compromise such as had characterised the period 1903-06.

The nature of Liberalism was, however, changing. Early-twentieth-century British elections mark a half-way point between older political divisions, based upon competing interest groups which often failed to coincide with class divisions, and an emerging political pattern in which the major factors, although their ubiquity is often exaggerated, in determining political allegiance become economic self-interest and class. An analysis of the results of the 1910 General Election has shown Unionist strength to have lain "mainly in the rural counties, the market, county and cathedral towns, in suburbia, spas and seaside resorts, and in the middle-class and commercial constituencies in the great cities" ${ }^{69}$ Liberal strength lay above all in industrial England, particularly in the North-East, Yorkshire and the East Midlands, and in Scotland and Wales. In this the broad electoral maps of Britain had changed little since 1885, and throughout this period economic factors had been important, but it was becoming tidier; it is significant, as Professor Blewett points out, ${ }^{70}$ that both major parties in the early twentieth century lost ground in areas where they had been traditionally strong and where their support is difficult to explain in economic terms - the 1910 elections emphasise a drift away from the Liberal Party in East Anglia, and the Unionists failed to regain the position in Lancashire and in London working-class constituencies that they had had prior to 1906.

The Liberal Party was increasingly dependent upon working-class voters as they faced the defection to Unionism of many of their middle-class supporters especially in the South. Dr Pelling has argued that the Asquith Government's social reforms were in response to pressure from middleclass reformers, who favoured reform partly for humanitarian reasons and partly because they thought it would be electorally popular, rather than in response to working-class demands. Whether or not the social-reform policies of the government had much appeal to the working-class voter, the combination of reform and increased taxation alienated many prominent and wealthy Liberals.

Liberalism in the North-East during this period does not correspond either to the model of Dr Clarke's Lancashire or Dr Morgan's Wales. The cultural preconditions for the politics of nonconformity still applied to a

69 Ibid., p. 401.

70 Ibid. 
considerable degree and gave a continuing vitality to the "old Liberalism". Liberalism could still rely upon traditional loyalties among working-class voters, nonconformists, industrialists and businessmen. The fact that the major threat to Liberalism's dominant position came from the Labour Party meant that the policy of the "progressive alliance" was, in the long run, bound to fail if Labour insisted on encroaching further than NorthEast Liberalism was prepared to concede. That policy had, however, been pursued somewhat patchily in 1906, and Liberal MPs such as J. Stuart, J. Craig and T. Cairns had been enthusiastic supporters, while in MacKinnon Robertson and Atherley Jones the "New Liberalism" can be said to have had its proponents. Whether because of traditional loyalties or because of the government's social-reform policies, North-East Liberalism was succeeding in retaining much of its working-class support, and it appeared by no means certain that organised labour's affiliation to the Labour Party would change working-class voting patterns. The government's socialreform policies did, however, test the loyalty of the Liberal Party's business supporters. Many leading Liberals like W. Runciman Sen. and Lord Furness were increasingly dissatisfied with policies which they saw as verging on Socialism. Nevertheless the party contrived until 1914 to retain many wealthy and middle-class supporters, and the traditional loyalty of nonconformity helped to prevent Liberal support in the North-East becoming a purely working-class phenomenon. The problem the party had to face was how to reconcile the varied interests of its supporters.

A weakness in the Liberal position was perhaps that it was increasingly reliant on success at a national level to give it electoral appeal while it weakened in the constituencies. A strength of nineteenth-century Liberalism had been the degree to which it represented provincial feeling and opinion to which its Parliamentary leadership was closely attuned. A. J. P. Taylor has called the fall of Asquith in 1916 the result of a "longdelayed revolt of the provinces against London's political and cultural dominance". ${ }^{71}$ As early as 1903 the London leadership considered some local Liberal associations expendable in the interests of success at Westminster. The advice of local leaders was ignored, and local associations at Barnard Castle and Chester-le-Street allowed to wither. Liberal organisation in the mining constituencies was dealt a severe blow by the affiliation of the mining unions to the Labour Party, as the miners' lodges had often acted as part of the Liberal electoral machinery. Weakness at a local level was to be an important element in Liberal decline in the 1920's.

71 A. J. P. Taylor, English History 1914-1945 (1965), p. 67. 
In 1914, however, the position of the Liberal Party in the North-East was still a dominant one. The number of Labour MPs representing constituencies in the region was four, exactly the same as in 1906 . Whether a general election in 1914 or 1915 would have seen a marked increase in this figure is, of course, an imponderable, but there is little evidence from the fortunes of Labour candidates in 1910 or at by-elections to suggest that the Labour Party was poised for a massive breakthrough. 